\title{
Biological Effects of Seed Irradiation by Synchrotron X Ray Beam in Young Bean Seedlings
}

\author{
Sonal Dhamgaye ${ }^{1}$, Nitu Gupta ${ }^{1}$, Aanchal Shrotriya ${ }^{1}, V^{2}$ shal Dhamgaye ${ }^{2}$, Rekha Gadre ${ }^{*}$ \\ ${ }^{1}$ School of Biochemistry, Devi Ahilya University, Takshashila Campus, Indore, Madhya Pradesh, India \\ ${ }^{2}$ Indus Synchrotrons Utilisation Division, Raja Ramanna Centre for Advanced Technology, Indore, Madhya Pradesh, India \\ Email: *rekhagadre29@gmail.com
}

How to cite this paper: Dhamgaye, S., Gupta, N., Shrotriya, A., Dhamgaye, V. and Gadre, R. (2019) Biological Effects of Seed Irradiation by Synchrotron X Ray Beam in Young Bean Seedlings. Advances in Biological Chemistry, 9, 88-97.

https://doi.org/10.4236/abc.2019.92007

Received: March 6, 2019

Accepted: April 27, 2019

Published: April 30, 2019

Copyright (c) 2019 by author(s) and Scientific Research Publishing Inc. This work is licensed under the Creative Commons Attribution International License (CC BY 4.0).

http://creativecommons.org/licenses/by/4.0/

\begin{abstract}
Irradiated seeds of Phaseolus vulgaris cv. Rajmah using Synchrotron X Ray Beam (BL-07) in RRCAT, Indore at doses of 1, 10 and 20 Gy were used to raise the seedling and the effects on growth and biochemical constituents in 4 - 8 days, old seedlings were analyzed. The seed irradiation effect on seedling development up to about 4 - 5 days, $\%$ germination, seedling length and seedling vigor are significantly decreased at 10 and 20 Gy doses with strong -ve correlation. Other parameters, like relative water content, electrical conductivity and acid phosphatase activity are also decreased. Decrease in various biochemical constituents, like, protein and proline has shown significant reduction at 10 and $20 \mathrm{~Gy}$ and phenol at $1-20 \mathrm{~Gy}$. However, peroxidase activity is increased at 1 and $10 \mathrm{~Gy}$. Amongst the antioxidant enzymes, only superoxide dismutase activity has shown significant increase at 10 and 20 Gy. For seed irradiation ( 1 and $10 \mathrm{~Gy}$ ) effect on seedling development up to 8 days involving transfer to hydroponic culture after 4 days, in shoot tissue, decrease in nitrate reductase activity and pigment content is observed, while nitrate reductase activity in root tissue is increased. The results demonstrate adverse effects on growth as well as biochemical constituents along with increased antioxidant effect in bean seedlings with irradiation of seeds at high dose of synchrotron $\mathrm{X}$ radiations. Also the nitrate assimilation and photosynthetic activity are reduced in shoot tissue with seed irradiation, however, increased nitrate reductase activity in roots suggests the involvement of NO signaling.
\end{abstract}

\section{Keywords}

Synchrotron Radiation, Phaseolus vulgaris, Bean Seedlings, Biochemical Effects 


\section{Introduction}

Agricultural crops face several challenges in the form of stresses leading to huge crop destruction and an overall decrease in the crop yield due to altered gene expression and metabolism, changes in growth and physiological processes, etc. in the plants. One of the important crop plants is the legume, Phaseolus vulgaris (common bean), that is grown for green vegetable and dry seeds. It has high protein, starch, dietary fiber and is rich in calcium, phosphorus, iron, selenium, molybdenum, thiamine, vitamine $\mathrm{B}_{6}$, folic acid, etc. Also the crop is economically important, as India is largest producer of dry beans with 10 million hectares areas of harvest.

Abiotic stress is a major global problem limiting crop productivity, as plants are being exposed to these in terrestrial environment. Ionising radiation, such as, ultraviolet, gamma and $\mathrm{x}$-rays which occurs naturally, is the most hazardous stress for all living systems. The significant sources of variation in radiation include altitude, relative abundance of radioactive isotopes in soils and nuclear accidents. The effect of nuclear accidents has been reported to affect the growth and development of surrounding plants [1]. On exposure to ionizing radiation, plants trigger oxidative stress due to generation of reactive oxygen species. The activation of scavenging enzymatic machinery may represent essential strategies to counteract cell oxidative damage, thus improving plant stress tolerance [2] [3]. Exposure to ionizing radiations, such as X-rays and gamma rays, is suggested to inflict physicochemical stresses thus affecting growth and physiological modifications [4]. The effects of ionizing radiation are largely damaging and detrimental at high doses. However, some reports provide evidence of a stimulating effect on growth when seeds or seedlings are exposed to low-dose ionizing radiation [5]. Most of the studies of radiation have been reported with gamma radiation [6] [7], a few with X radiations [5] [8], but studies involving synchrotron radiations are lacking. Using synchrotron radiations our earlier study has been reported for growth retardation effects in bean seedlings [9]. In continuation of this, in the present investigation biochemical effects of synchrotron radiations at higher doses (10 and $20 \mathrm{~Gy}$ ) have been analyzed using young (4 - 8 days old) bean seedlings. The seeds were exposed to various energies at BL-07, Indus-2 RRCAT, Indore for monitoring the effects.

\section{Material and Methods}

Seeds of Phaseolus vulgaris cv. Rajmah purchased from Pahuja Seeds, New Delhi were irradiated by using Indus-2 Synchrotron X Ray Beam (BL-07) at RRCAT, Indore in the doses 1,10 and $20 \mathrm{~Gy}$. For seed irradiation total 100 seeds were packaged without any overlapping in polythene bag of size $30 \mathrm{~mm} \times 50 \mathrm{~mm}$ and exposed to $\mathrm{x}$ radiations in air and at $25^{\circ} \mathrm{C}$ using $6-11 \mathrm{keV} \mathrm{x}$-ray energy range. Irradiated seeds were surface sterilized with $0.1 \% \mathrm{HgCl}_{2}$ for $1-2$ minutes followed by thorough washing with distilled water. To evaluate the effects of irradiation, the seedlings were raised in petri plates for 4 - 5 days in continuous light 
supplied by fluorescent tubes in Plant Growth Chamber at $25^{\circ} \mathrm{C} \pm 2^{\circ} \mathrm{C}$. Seedlings from respective doses were used for analysis of various parameters. Seedling length and \% germination were analyzed in 4 - 5 days old seedlings to calculate the seedling vigor. Relative water content (RWC) and Electrical conductivity (EC) were measured respectively, by the method of Barr and Weatherley [10] and Wahid et al., [11]. The acid phosphatase activity was extracted and assayed by measuring p-nitrophenol (PNP) spectrophotometrically at $410 \mathrm{~nm}$ according to the method of Prazeres et al. [12].

The key biochemical constituents, total protein was measured by the method of Lowry et al. [13], proline by the method of Bates et al. [14] and total phenol by the method of Bray and Thorpe et al., [15]. For the assay of Guiacol peroxidase activity the method of Putter was used [16]. The enzyme of antioxidant system, Superoxide Dismutase (SOD), was assayed in terms of reduction of Nitroblue Tetrazolium (NBT) according to the method as described by Beauchamp and Fridovich [17]. Catalase (CAT) activity was assayed spectrophotometrically by monitoring decrease in absorbance at $240 \mathrm{~nm}$ according to the method of Aebi [18]. Ascorabte peroxidise (APX) activity was determined spectrophotometrically by the method of Nakona and Asada [19].

In another set of experiments, the petriplate grown 4 - 5 days old seedlings were transferred to separate test tubes containing $1 / 2$ strength Hoagland's nutrient medium with $5 \mathrm{mM} \mathrm{NH}_{4} \mathrm{NO}_{3}$ and raised under similar conditions for further 4 days. In these 8 days old seedlings, in vivo NRA of the root and shoot tissue was assayed based on colorimetric estimation of nitrite by the method of Srivastava [20]. The pigments, chlorophyll and carotenoids were extracted from the shoot tissue using $80 \%$ acetone and estimated spectrophotometrically by measuring the absorbance at $470 \mathrm{~nm}, 646 \mathrm{~nm}$, and $663 \mathrm{~nm}$. The pigment content was calculated using the following equations according to the method of Lichtenthaler and Welburn [21].

$$
\begin{gathered}
\text { Chl a }\left(\mu \mathrm{g} \cdot \mathrm{ml}^{-1}\right)=12.21\left(\mathrm{~A}_{663}\right)-2.81\left(\mathrm{~A}_{646}\right) \\
\mathrm{Chl} \mathrm{b}\left(\mu \mathrm{g} \cdot \mathrm{ml}^{-1}\right)=20.13\left(\mathrm{~A}_{646}\right)-5.03\left(\mathrm{~A}_{663}\right) \\
\text { Total Chlorophyll }=\mathrm{Chl} \mathrm{a}+\mathrm{Chl} \mathrm{b} \\
\text { Caratenoids }\left(\mu \mathrm{g} \cdot \mathrm{ml}^{-1}\right)=1000\left(\mathrm{~A}_{470}\right)-3.27(\mathrm{Chl} \mathrm{a})-104(\mathrm{Chl} \mathrm{b}) / 229 .
\end{gathered}
$$

Results expressed are the average values of at least three independent experiments with \pm SE. Difference between means obtained was tested by Student's $t$ test at level of significance- ${ }^{*} \mathrm{p}<0.05,{ }^{* *} \mathrm{p}<0.01,{ }^{* *} \mathrm{p}<0.001$. For correlation analysis XY scatter charts were prepared and correlation coefficient, $R^{2}$, values are given.

\section{Results and Discussion}

1) Effect of seed irradiation on Growth of 4 - 5 days old bean seedlings

$\mathrm{X}$ ray irradiation (1, 10 and $20 \mathrm{~Gy}$ ) of bean seeds used for seedling development decreased various growth parameters, measured as, Germination \%, seedling length and seedling vigor in 4 - 5 days old young seedlings. All growth parame- 
ters were decreased with irradiation in dose dependent manner and the decrease was significant at higher dose i.e. 10 and $20 \mathrm{~Gy}$ (Table 1). The correlation coefficient $\left(\mathrm{R}^{2}\right)$ for germination \%, seedling length and seedling vigor were $0.95,0.658$, 0.775, respectively, which showed strong correlation with irradiation dose (Table 1). Other parameters used for monitoring growth, RWC and EC, were decreased significantly at higher dose i.e. 10 and $20 \mathrm{~Gy}$ with the correlation coefficient $\left(\mathrm{R}^{2}\right)$ for RWC and EC being 0.339 and 0.897 , respectively (Table 2 ). Effect of seed irradiation on seedling development analyzed as acid phosphatase activity was found to be reduced at all the doses tested (Table 2). The observed $\mathrm{R}^{2}$ value was 0.587 , but the effect was nonsignificant.

2) Effect of seed irradiation on Biochemical Constituents and Antioxidant Enzymes of 4 - 5 days old bean seedlings

The biochemical constituents studied for irradiation effects on seedlings development have shown varying effects depending upon the parameter and dose. Thus, significant reduction in protein and proline content was observed at 10 and 20 Gy doses with perfect correlation having $\mathrm{R}^{2}$ values of 0.983 and 0.921 , respectively (Table 3 ). The phenol content was reduced significantly at all the doses having correlation coefficient value of 0.759 (Table 3 ). On the other hand, the peroxidase activity was increased at 1 and $10 \mathrm{~Gy}$ and remained unaffected at 20 Gy with observed correlation coefficient of 0.193 only (Table 3 ). Amongst the activities of antioxidant enzymes, like, SOD, CAT and APX, the SOD activity was not affected at $1 \mathrm{~Gy}$ dose but significantly induced at 10 and $20 \mathrm{~Gy}$ doses (Table 4). Also the strong correlation was observed with $\mathrm{R}^{2}$ value of 0.891 . The CAT activity remained almost unaffected at all the doses tested, while APX activity was increased at 10 and $20 \mathrm{~Gy}$, though nonsignificantly (Table 4). The correlation coefficient $\left(\mathrm{R}^{2}\right)$ for CAT and APX were 0.307 and 0.806 , respectively (Table 4).

3) Effect of seed irradiation on key physiological processes of 4 - 5 days old bean seedlings

For analysis of nitrate reductase activity and pigment content, 4 day old seedlings were transferred to Hoagland medium with $5 \mathrm{mM} \mathrm{NH}_{4} \mathrm{NO}_{3}$ contained in test tubes for further 4 days and root and/or shoot tissue was used. Thus in 8

Table 1. Effect of seed irradiation on Germination and Growth parameters in 4 - 5 days old bean seedlings. Seedlings were raised from irradiated seeds in petriplates moistened with filter paper for $4-5 \mathrm{~d}$ in continuous light at $25^{\circ} \mathrm{C} \pm 2{ }^{\circ} \mathrm{C}$ inside growth chamber.

\begin{tabular}{cccc}
\hline Irradiation Dose, Gy & Germination, \% & Seedling Length, cm & Seedling Vigor, \% G*L \\
\hline 0 & $71 \pm 4.2(100)$ & $1.65 \pm 0.1(100)$ & $117 \pm 11.7(100)$ \\
1 & $63 \pm 5.7(88)$ & $1.32 \pm 0.13(80)$ & $83 \pm 12.6(70)$ \\
10 & $51 \pm 7.7^{*}(71)$ & $0.93 \pm 0.12^{\star * *}(56)$ & $47 \pm 12^{\star * \star}(40)$ \\
20 & $40 \pm 7^{* *}(56)$ & $0.98 \pm 0.16^{* *}(59)$ & $39 \pm 10.8^{* * *}(33)$ \\
$\mathrm{R}^{2}$ & $\mathbf{0 . 9 5}$ & $\mathbf{0 . 6 8 5}$ & $\mathbf{0 . 7 7 5}$ \\
\hline
\end{tabular}

Values relative to control are given in parentheses. Level of significance: ${ }^{\star} \mathrm{p}$ value $<0.05,{ }^{* *} \mathrm{p}$ value $<0.01$, ${ }^{* * *} \mathrm{p}$ value $<0.001$ 
Table 2. Effect of seed irradiation on RWC, EC and Acid phosphatase activity in 4 - 5 days old bean seedlings. Seedlings were raised from irradiated seeds in petriplates moistened with filter paper for $4-5 \mathrm{~d}$ in continuous light at $25^{\circ} \mathrm{C} \pm 2{ }^{\circ} \mathrm{C}$ inside growth chamber.

\begin{tabular}{cccc}
\hline $\begin{array}{c}\text { Irradiation } \\
\text { Dose, Gy }\end{array}$ & $\begin{array}{c}\text { Relative Water } \\
\text { Content, } \%\end{array}$ & $\begin{array}{c}\text { Electrical Conductivity } \\
\text { X100, } \mu \mathrm{S} / \mathrm{cm}\end{array}$ & $\begin{array}{c}\text { Acid phosphatase, } \mu \text { moles } \\
\mathrm{PNP} \mathrm{min}^{-1} \cdot \mathrm{mg}^{-1} \text { protein }\end{array}$ \\
\hline 0 & $85 \pm 4(100)$ & $21 \pm 0.5(100)$ & $4.9 \pm 1.4(100)$ \\
1 & $75 \pm 2(88)$ & $20 \pm 1.0(95)$ & $3.1 \pm 0.6(63)$ \\
10 & $79 \pm 2(92)$ & $16 \pm 2.0(76)$ & $2.6 \pm 0.4(53)$ \\
20 & $74 \pm 6(87)$ & $15 \pm 0.6(71)$ & $2.3 \pm 0.5(46)$ \\
$\mathbf{R}^{2}$ & $\mathbf{0 . 3 3}$ & $\mathbf{0 . 8 9}$ & $\mathbf{0 . 5 8 3}$ \\
\hline
\end{tabular}

Values relative to control are given in parentheses. Level of significance: $p$ values non significant.

Table 3. Effect of seed irradiation on Protein, Proline, Phenol content and Peroxidase activity in 4 - 5 days old bean seedlings. Seedlings were raised from irradiated seeds in petriplates moistened with filter paper for $4-5 \mathrm{~d}$ in continuous light at $25^{\circ} \mathrm{C} \pm 2{ }^{\circ} \mathrm{C}$ inside growth chamber.

\begin{tabular}{ccccc}
\hline $\begin{array}{c}\text { Irradiation } \\
\text { dose, Gy }\end{array}$ & $\begin{array}{c}\text { Protein, } \\
\mathrm{mg} \cdot \mathrm{g}^{-1} \mathrm{fr} w \mathrm{wt}\end{array}$ & $\begin{array}{c}\text { Proline, } \\
\mathrm{mg} \cdot \mathrm{g}^{-1} \mathrm{fr} \mathrm{wt}\end{array}$ & $\begin{array}{c}\text { Phenol, } \\
\mu \mathrm{g} \cdot \mathrm{g}^{-1} \mathrm{fr} w \mathrm{wt}\end{array}$ & $\begin{array}{c}\text { Peroxidase, } \Delta \mathrm{A} \\
\mathrm{min}^{-1} \cdot \mathrm{g}^{-1} \mathrm{fr} \mathrm{wt}\end{array}$ \\
\hline 0 & $60 \pm 1.2(100)$ & $0.71 \pm 0.05(100)$ & $1.2 \pm 0.04(100)$ & $0.90 \pm 0.22(100)$ \\
1 & $53 \pm 4.3(89)$ & $0.70 \pm 0.08(98)$ & $0.9 \pm 0.02^{* * *}(75)$ & $2.1 \pm 0.28^{\star}(233)$ \\
10 & $39 \pm 3.1^{*}(65)$ & $0.31 \pm 0.01^{* * *}(43)$ & $0.7 \pm 0.03^{* * *}(58)$ & $1.46 \pm 0.25(162)$ \\
20 & $22 \pm 1.4^{* * *}(37)$ & $0.20 \pm 0.01^{* * *}(28)$ & $0.6 \pm 0.038^{* *}(50)$ & $0.88 \pm 0.28(98)$ \\
$\mathbf{R}^{2}$ & $\mathbf{0 . 9 8 3}$ & $\mathbf{0 . 9 2 1}$ & $\mathbf{0 . 7 5 9}$ & $\mathbf{0 . 1 9 3}$ \\
\hline
\end{tabular}

Values relative to control are given in parentheses. Level of significance: ${ }^{*} \mathrm{p}$ value $<0.05,{ }^{* *} \mathrm{p}$ value $<0.01$, ${ }^{* * *} \mathrm{p}$ value $<0.001$.

Table 4. Effect of seed irradiation on Superoxide dismutase, Catalase and Ascorbate peroxidase activity in 4 - 5 days old bean seedlings. Seedlings were raised from irradiated seeds in petriplates moistened with filter paper for $4-5 \mathrm{~d}$ in continuous light at $25^{\circ} \mathrm{C} \pm$ $2^{\circ} \mathrm{C}$ inside growth chamber.

\begin{tabular}{cccc}
\hline $\begin{array}{c}\text { Irradiation } \\
\text { Dose, } \mathrm{Gy}\end{array}$ & $\begin{array}{c}\text { Superoxide dismutase, } \\
\text { units } \mathrm{mg}^{-1} \text { protein }\end{array}$ & $\begin{array}{c}\text { Catalase, nmoles } \mathrm{H}_{2} \mathrm{O}_{2} \\
\text { decomposed } \mathrm{min}^{-1} \cdot \mathrm{mg}^{-1} \\
\text { protein }\end{array}$ & $\begin{array}{c}\text { Ascorbate peroxidase, } \\
\text { nmoles ascorbic acid oxidized } \\
\mathrm{min}^{-1} \cdot \mathrm{mg}^{-1} \mathrm{protein}^{-}\end{array}$ \\
\hline 0 & $0.083 \pm 0.04(100)$ & $0.0065 \pm 0.0006(100)$ & $0.005 \pm 0.0009(100)$ \\
1 & $0.05 \pm 0.02(60)$ & $0.007 \pm 0.0004(108)$ & $0.005 \pm 0.0005(100)$ \\
10 & $0.21 \pm 0.02^{* *}(253)$ & $0.007 \pm 0.0006(108)$ & $0.006 \pm 0.0008(120)$ \\
20 & $0.25 \pm 0.05^{*}(301)$ & $0.007 \pm 0.0007(108)$ & $0.006 \pm 0.001(120)$ \\
$\mathbf{R}^{2}$ & $\mathbf{0 . 8 9 1}$ & $\mathbf{0 . 3 0 7}$ & $\mathbf{0 . 8 0 6}$ \\
\hline
\end{tabular}

Values relative to control are given in parentheses. Level of significance: ${ }^{\star} \mathrm{p}$ value $<0.05,{ }^{* *} \mathrm{p}$ value $<0.01$.

days old seedlings, the nitrate reductase activity of the root was increased, but decreased in the shoot with perfect correlation having $\mathrm{R}^{2}=0.986$ and 0.999 , respectively (Table 5). The observed effect was significant at $10 \mathrm{~Gy}$ in shoot tissue 
Table 5. Effect of seed irradiation on Nitrate reductase activity in root and shoot, total Chlorophyll and Carotenoid content in shoot of 8 days old bean seedlings. Seedlings were raised from irradiated seeds in petriplates moistened with filter paper for $4-5 \mathrm{~d}$ in continuous light at $25^{\circ} \mathrm{C} \pm 2{ }^{\circ} \mathrm{C}$ inside growth chamber and transferred to a $1 / 2$ strength Hoagland's nutrient medium with $5 \mathrm{mM} \mathrm{NH}_{4} \mathrm{NO}_{3}$ contained in test tubes for another 4 days.

\begin{tabular}{ccccc}
\hline $\begin{array}{c}\text { Irradiation dose, } \\
\mathrm{Gy}\end{array}$ & $\begin{array}{c}\text { Root NRA, nmoles } \\
\mathrm{NO}_{2} \mathrm{~h}^{-1} \cdot \mathrm{g}^{-1} \mathrm{fr} \mathrm{wt}\end{array}$ & $\begin{array}{c}\text { Shoot NRA, nmoles } \\
\mathrm{NO}_{2} \mathrm{~h}^{-1} \cdot \mathrm{g}^{-1} \mathrm{fr} \mathrm{wt}\end{array}$ & $\begin{array}{c}\text { Chlorophyll, } \\
\mu \mathrm{g} \cdot \mathrm{g}^{-1} \mathrm{fr} w \mathrm{wt}\end{array}$ & $\begin{array}{c}\text { Carotenoid, } \\
\mu \mathrm{g} \cdot \mathrm{g}^{-1} \mathrm{fr} w \mathrm{wt}\end{array}$ \\
\hline 0 & $176 \pm 47(100)$ & $174 \pm 21(100)$ & $102 \pm 27(100)$ & $6.9 \pm 2.2(100)$ \\
1 & $261 \pm 57(148)$ & $169 \pm 56(97)$ & $82 \pm 6(80)$ & $5.6 \pm 2.0(81)$ \\
10 & $567 \pm 214(322)$ & $98 \pm 17^{*}(56)$ & $81 \pm 7(79)$ & $3.9 \pm 1.9^{*}(56)$ \\
$\mathbf{R}^{2}$ & 0.986 & 0.999 & 0.372 & 0.867 \\
\hline
\end{tabular}

Values relative to control are given in parentheses. Level of significance: ${ }^{*} \mathrm{p}$ value $<0.05$.

only. For pigment content measured in shoot tissue, total chlorophylls and carotenoid content were reduced at 1 and $10 \mathrm{~Gy}$ both and the correlation coefficient values were 0.372 and 0.867 , respectively (Table 5 ). The observed effect was significant at $10 \mathrm{~Gy}$ for carotenoid content only.

The present study analyses growth, biochemical constituents, antioxidative enzymes and key physiological processes in bean seedlings developed from seeds irradiated with synchrotron $x$ rays. Plant exposure to ionizing radiations in the vicinity of nuclear accidents to influence growth and development has been observed [1]. Using diagnostic doses of $\mathrm{x}$ rays accelerated growth of Phsaeolus vulgaris [5] and increased root length at 0.05 - 15 Gy and leaf wt at low doses in date palm [22] have been reported. However, using synchrotron radiations for seed exposure at 0.5 - 5 Gy doses retarded growth of bean seedlings resulted [9]. In the present system using high doses, 10 and $20 \mathrm{~Gy}$, growth effects were significantly reduced by irradiation of the seeds used for seedling development. Thus, in 4 - 5 days old seedlings, \% germination, seedling length and seedling vigour are significantly decreased with strong -ve correlation (Table 1). Other growth parameters such as, RWC, a measure of water uptake capacity, and EC, related to membrane damage are also reduced (Table 2) with a more prominent effect for later suggesting an effect on ion leakage due to seed irradiation. The phosphate mobilization involving acid phosphatase activity is of importance during germination, as it is induced with germination [12] [23]. Decreased activity of acid phosphatase in seedlings developed from irradiated seeds (Table 2) indicates an effect on phosphate mobilization.

Seedling development process being complex depends on a number of biochemical constituent and physiological processes. Amongst the biochemical constituents, like, protein and proline have shown significant reduction at high doses (Table 3) reflecting reduction in overall metabolic status but increased osmotic stress. Proline plays a highly beneficial role in plants exposed to various stress conditions by acting as an osmolyte for osmotic adjustment and also by stabilizing sub-cellular structures, scavenging free radicals and buffering cellu- 
lar redox potential under stress conditions [24]. With the reduced phenolic contents at all the doses tested is indicative of reduced adaptation against environmental stresses. However, increased peroxidase activity at 1 and $10 \mathrm{~Gy}$ dose suggests the involvement of oxidative stress due to irradiation. Further, enhanced activity of SOD in response to higher doses of irradiation indicates requirement for scavenging of high content of superoxide radicals formed under high dose of X-ray irradiation. Thus exposure to synchrotron $\mathrm{x}$ radiations seems to trigger oxidative stress in bean seedlings. The activation of scavenging enzymatic machinery may represent essential strategies to counteract cell oxidative damage, thus improving plant stress tolerance [2] [3].

For seed irradiation ( 1 and $10 \mathrm{~Gy}$ ) effect on seedling development up to 8 days involving transfer to hydroponic culture after 4 days, nitrate reductase activity and pigment content are analysed. Availability of nitrogen is an important factor limiting plant growth and development. Nitrate reductase catalyses the first and rate-limiting step of nitrate assimilation in fungi, algae and higher plants [25] and often limits plant productivity. NRA reflects the overall nitrogen status of the plant and high activity may also indicate the involvement of NO signaling. Plant pigments are essential molecules that are responsible for harvesting solar energy in photosynthetic antenna systems, and for charge separation and electron transport within reaction centers. Chlorophylls are often measured to assess the impact of environmental factors including pollutants, as the pigment content is correlated to visual symptoms and also photosynthetic plant productivity. The effect of $x$-ray irradiation on NRA has been reported in an earlier study in leaves of bean seedlings [9], but the effects on photosynthetic pigments have not been reported yet. Though the increased expression of Ribulose bis phosphate carboxylase and decreased expression of poly (ADP-ribose) polymerase in response to irradiation of dwarf bean plants by $\mathrm{x}$-radiations has been reported [8]. In the present investigation, decrease in nitrate reductase activity and pigment content in shoot tissue has resulted (Table 5), that reflects reduced nitrogen status and photosynthetic activity of the seedling to limit the growth. However, increased nitrate reductase activity in root tissue suggests the involvement of NO stress, as NR has been reported to mediate the synthesis of NO [26]. Moreover involvement of NO signaling in response to salinity stress has been suggested in bean seedlings based upon reduced growth and increased NRA [27].

\section{Conclusion}

Biological effects of seed irradiation of Phaseolus vulgaris cv. Rajmah using Synchrotron X Ray Beam on seedling development were monitored. Seed irradiation reduced \% germination, seedling length, seedling vigor, RWC, EC and acid phosphatase activity, indicating an effect on membrane damage and phosphate mobilization. Reduction in biochemical constituents, like, protein, proline, and phenolic contents reflects reduced metabolic status, increased osmotic stress and reduced adaptation against environmental stresses. Increased peroxidase activity 
and SOD in response to seed irradiation suggest the involvement of oxidative stress. Decrease in nitrate reductase activity and pigment content in shoot reflects reduced nitrogen status and photosynthetic activity, while, increased nitrate reductase activity in root tissue suggests the involvement of NO stress.

\section{Acknowledgements}

The Project Grant to RG and Fellowship to SD by UGC-DAE Consortium for Scientific Research, Indore (CSR-IC-BL24/CRS-121-2014-15/1217 dt 27/3/2015) are acknowledged.

\section{Conflicts of Interest}

The authors declare no conflicts of interest regarding the publication of this paper.

\section{References}

[1] Sidorov, V.P. (1994) Cytogenic Effect in Pinus Sylvestris Needle Cells as a Result of the Chernobyl Accident Radiation Biology. Radioecology, 34, 847-851.

[2] Alscher, R.G., Donahue, J.L. and Cramer, C.L. (1997) Reactive Oxygen Species and Antioxidants: Relationships in Green Cells. Physiologia Plantarum, 100, 224-233. https://doi.org/10.1111/j.1399-3054.1997.tb04778.x

[3] Esnault, M.A., Legue, F. and Chenal, C. (2010) Ionizing Radiation: Advances in Plant Response. Environmental and Experimental Botany, 68, 231-237. https://doi.org/10.1016/j.envexpbot.2010.01.007

[4] Ahloowalia, B.S. and Maluszynski, M. (2001) Induced Mutations-A New Paradigm in Plant Breeding. Euphytica, 118, 167-173.

[5] Mortzavi, S.M.J., Mehdi-Pour, L.A., Tanavardi, S., Mohammadi, S., Kazempour, S., Fatehi, S., Behnejad, B. and Mozdarani, H. (2006) The Biopositive Effects of Diagnostic Doses of X-Rays on Growth of Phaseolus vulgaris Plant: A Possibility of New Physical Fertilizers. Asian Journal of Experimental Biological Sciences, 20, 27-33.

[6] Maity, J.P., Mishra, D., Chakraborty, A., Saha, A., Santra, S.C. and Chanda, S. (2005) Modulation of Some Quantitative and Qualitative Characteristics in Rice (Oryza sativa L.) and Mung (Phaseolus mungo L.) by Ionizing Radiation. Radiation Physics and Chemistry, 74, 391-394. https://doi.org/10.1016/j.radphyschem.2004.08.005

[7] De Micco, V., Arena, C., Pignalosa, D. and Durante, M. (2011) Effects of Sparsely and Densely Ionizing Radiation on Plants. Radiation and Environmental Biophysics, 50, 1-19. https://doi.org/10.1007/s00411-010-0343-8

[8] Arena, C., De Micco, V. and De Maio, A. (2014) Growth Alteration and Leaf Biochemical Responses in Phaseolus vulgaris Exposed to Different Doses of Ionising Radiation. Plant Biology, 16, 194-202. https://doi.org/10.1111/plb.12076

[9] Dhamgaye, S., Dhamgaye, V. and Gadre, R. (2018) Growth Retardation at Different Stages of Bean Seedlings Developed from Seeds Exposed to Synchrotron X-Ray Beam. Advances in Biological Chemistry, 8, 29-35.

https://doi.org/10.4236/abc.2018.82003

[10] Barr, H.D. and Weatherley, P.E. (1962) A Re-Examination of the Relative Turgidity Technique for Estimating Water Deficits in Leaves. Australian Journal of Biological 
Sciences, 15, 413-428. https://doi.org/10.1071/BI9620413

[11] Wahid, A., Perveen, M., Gelani, S. and Basra, S.M. (2007) Pretreatment of Seed with $\mathrm{H}_{2} \mathrm{O}_{2}$ Improves Salt Tolerance of Wheat Seedlings by Alleviation of Oxidative Damage and Expression of Stress Proteins. Journal of Plant Physiology, 164, 283-294. https://doi.org/10.1016/j.jplph.2006.01.005

[12] Prazeres, J.N., Ferreira, C.V. and Aoyama, H. (2004) Acid Phosphatase Activities during the Germination of Glycine max Seeds. Plant Physiology and Biochemistry, 42, 15-20. https://doi.org/10.1016/j.plaphy.2003.10.009

[13] Lowry, O.H., Rosebrough, N.J., Farr, A.C. and Randall, R.J. (1951) Protein Measurement with the Folin-Phenol Reagent. Journal of Biological Chemistry, 193, 265-275.

[14] Bates, L.S., Walderren, R.P. and Teare, I.D. (1973) Rapid Determination of Free Proline for Water-Studies. Plant Soil, 39, 205-207. https://doi.org/10.1007/BF00018060

[15] Bray, H.G. and Thorpe, W.V. (1954) Analysis of Phenolic Compounds of Interest in Metabolism. In: Glick, D., Ed., Methods of Biochemical Analysis, John Wiley \& Sons, Inc., New York, 1, 27-52. https://doi.org/10.1002/9780470110171.ch2

[16] Pütter, J. (1974) Peroxidases. In: Bergmeyer, H.U., Ed., Methods of Enzymatic Analysis, Vol. 2, 2nd Edition, Academic Press, New York and London, 685-690. https://doi.org/10.1016/B978-0-12-091302-2.50033-5

[17] Beauchamp, C. and Fridovich, I. (1971) Superoxide Dismutase: Improved Assays and an Assay Applicable to Acrylamide Gels. Analytical Biochemistry, 44, 276-287. https://doi.org/10.1016/0003-2697(71)90370-8

[18] Aebi, H.E. (1983) Catalase. In: Bergmeyer, H.U., Ed., Methods of Enzymatic Analysis, Verlag Chemie, Weinheim, Deutschland, 273-286.

[19] Nakona, Y. and Asada, K. (1981) Hydrogen Peroxide Is Scavenged by Ascorbic Specific Peroxidase in Spinach Chloroplasts. Plant and Cell Physiology, 22, 867-880. https://doi.org/10.1093/oxfordjournals.pcp.a076232

[20] Srivastava, H.S. (1975) Distribution of Nitrate Reductase in Bean Seedlings. Plant and Cell Physiology, 16, 995-999.

https://doi.org/10.1093/oxfordjournals.pcp.a075245

[21] Lichtenthaler, H.K. and Welburn, A.R. (1983) Determination of Total Carotenoids and Chlorophylls $a$ and $b$ of Extracts in Different Solvents. Biochemical Society Transactions, 11, 591-592. https://doi.org/10.1042/bst0110591

[22] Al-Enezi, N.A., Al-Bahrany, A.M. and Al-Khayri, J.M. (2012) Effect of X-Irradiation on Date Palm Seed Germination and Seedling Growth. Emirates Journal of Food and Agriculture, 24, 415-424.

[23] Serenna, R., Simonin, V., Silva-Neto, M.A.C. and Fialho, E. (2006) Induction of Acid Phosphatase Activity during Germination of Maize (Zea mays) Seeds. Plant Physiology and Biochemistry, 44, 467-473. https://doi.org/10.1016/j.plaphy.2006.03.008

[24] Ashraf, M. and Foolad, M.R. (2007) Roles of Glycine Betain and Proline in Improving Plant Abiotic Stress Resistance. Environmental and Experimental Botany, 59, 206-216. https://doi.org/10.1016/j.envexpbot.2005.12.006

[25] Campbell, W.H. (2001) Structure and Function of Eukaryotic NAD(P)H: Nitrate Reductase. Cellular and Molecular Life Sciences CMLS, 53, 194-204. https://doi.org/10.1007/PL00000847

[26] Rockel, P., Strube, F., Rockel, A., Wildt, J. and Kaiser, W.M. (2002) Regulation of 
Nitric Oxide (NO) Production by Plant Nitrate Reductase in Vivo and in Vitro. Journal of Experimental Botany, 53, 103-110.

https://doi.org/10.1093/jexbot/53.366.103

[27] Dhamgaye, S. and Gadre, R. (2015) Salinity Stress Effects on Growth and Nitrate Assimilation in Bean Seedlings Likely to Be Mediated via Nitric Oxide. Journal of Stress Physiology and Biochemistry, 11, 137-146. 